\title{
"Hunger was never absent": How residential school diets shaped current patterns of diabetes among Indigenous peoples in Canada
}

\author{
n Cite as: CMAJ 2017 August 14;189:E1043-5. doi: 10.1503/cmaj.170448
}

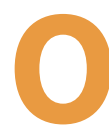

ne of the most consistent themes in testimony provided to the Truth and Reconciliation Commission of Canada (TRC) was the common experience of hunger at residential schools. In his statement to the TRC, survivor Andrew Paul spoke of the unrelenting hunger he experienced during his time at Aklavik Roman Catholic Residential School: "We cried to have something good to eat before we sleep. A lot of the times the food we had was rancid, full of maggots, stink. Sometimes we would sneak away from school to go visit our aunts or uncles, just to have a piece of bannock." Ray Silver described how he and other children at the Alberni Indian Residential School coped with persistent hunger: "And us kids, we used to sneak from the school ... and go to that dump, and pick up apples, they were half rotten or something, and ... were no more good to sell, but us kids that were starving, we'd go there and pick that stuff up, fill up our shirts, and run back across the bridge, and go back to the school." ${ }^{\prime}$

Such accounts, of course, are not new. In 1965, Indian Affairs Branch employee Russell Moses - who attended the Mohawk Institute in Brantford, Ontario, from 1942 to 1947 - described a typical diet where "hunger was never absent." Breakfast consisted of "two slices of bread with either jam or honey as the dressing, oatmeal with worms or corn meal porridge, which was minimal in quantity and appalling in quality." For lunch, it was "water as the beverage ... one and a half slices of dry bread, and the main course consisted of a 'rotten soup' ... (i.e., scraps of beef, vegetables, some in a state of decay)." For supper, "stu-

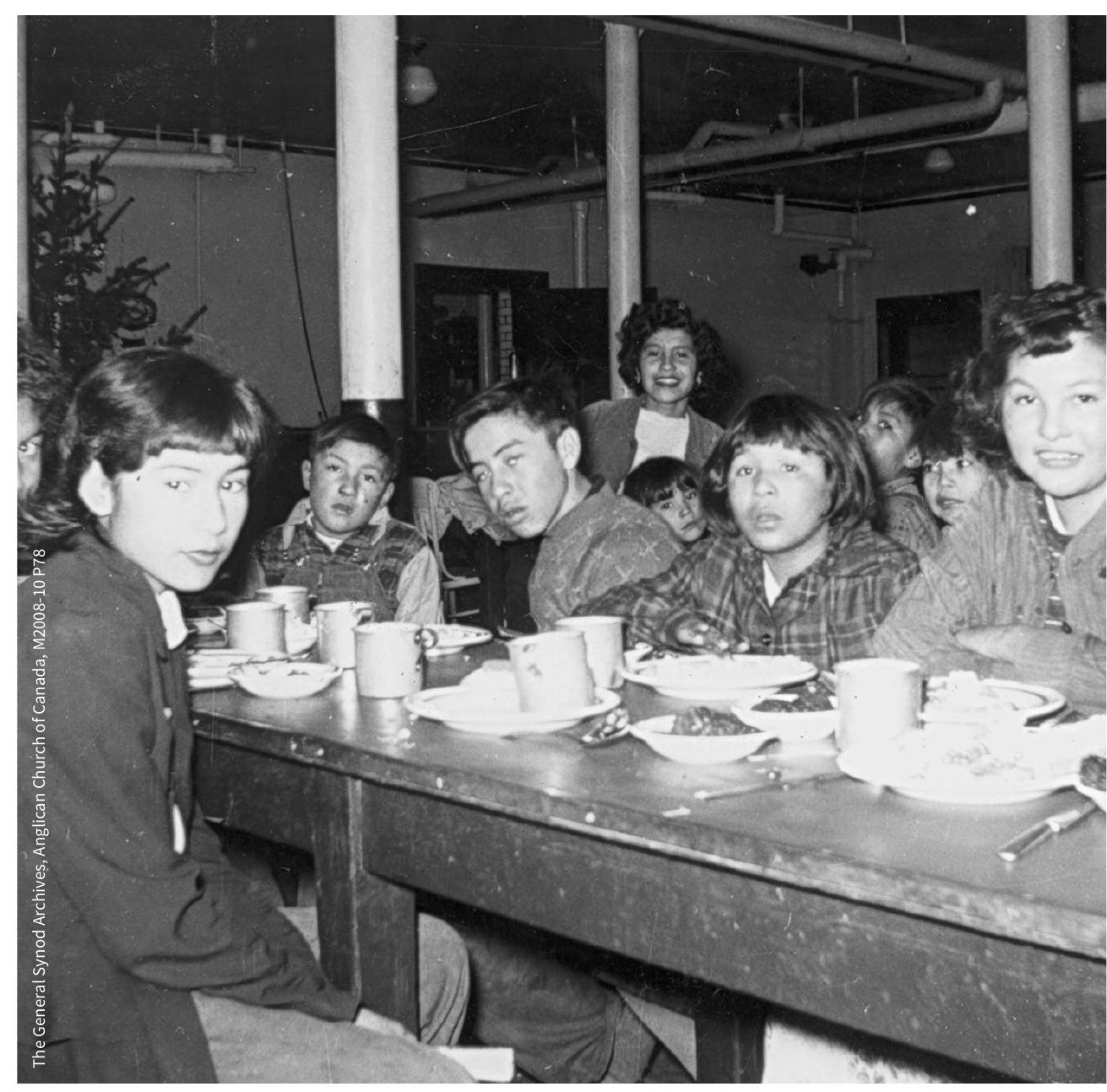

Meal time at Gordon's School in January 1954, from the Grace Reed Fonds.

dents were given two slices of bread and jam, fried potatoes, no meat [and] a bun baked by the girls." Moses even recalled hungry children "eating from the swill barrel, picking out soggy bits of food that was intended for the pigs." In 1988, Basil Johnson wrote that, during his time at the Indian Residential School in Spanish, Ont., between 1939 and 1950, "the abid- ing condition was hunger" and students were fed just enough "to blunt the sharp edge of hunger for three or four hours, never enough to dispel hunger completely until the next meal." 3

The extent to which such accounts of hunger are common across diverse geographies and time periods led residential schools historian J.R. Miller to remark in 
1996 that “'We were always hungry' could serve as the slogan for any organization of former residential school students."4 This sad reality is only highlighted by the fact that hunger was so widespread that nearly 1000 malnourished students at six residential schools were used as subjects in a series of nutrition experiments between 1948 and 1952. ${ }^{5}$ their history, the average daily caloric intake tended to range between 1000 and $1450 \mathrm{kcal} /$ day at a typical residential school. ${ }^{7}$ (Energy requirements for moderately active, healthy children ages 4-18 yr range from 1400 to $3200 \mathrm{kcal} / \mathrm{d} .{ }^{8}$ )

This level of hunger and malnutrition undoubtedly had substantial consequences for a child's growth and develop-

\section{"Sustained exposure to caloric} restriction ... produces a biological complex of height stunting together with metabolic changes that lead to greater risk of obesity
and chronic disease."

While it is difficult to quantify with any accuracy the nutritional intake of children attending residential schools - and while there were clearly some exceptions there is sufficient consistency among survivors' accounts to state that, for most of the schools' history, the typical residential school diet was characterized by insufficient caloric intake, minimal protein and fat, severely limited access to fresh fruit and vegetables, and frequent bouts of food-borne infection. As the TRC concluded:

The federal government knowingly chose not to provide schools with enough money to ensure that kitchens and dining rooms were properly equipped, that cooks were properly trained, and, most significantly, that food was purchased in sufficient quantity and quality for growing children. It was a decision that left thousands of Aboriginal children vulnerable to disease. ${ }^{6}$

The full cost of that decision has yet to be reckoned. Take the diet described by Russel Moses which, we estimate, describes a maximum of $1260 \mathrm{kcal} /$ day. The same is true of other survivor accounts we have analyzed, which suggest that well-fed students were the exception - not the rule - at these schools and that, for most of ment. A recent review of studies in highpoverty environments where chronic undernutrition is endemic, and in socalled "natural experiments" arising from 20th-century famine events, reveals a range of biological effects of sustained caloric restriction. ${ }^{7}$ of these, the most important is height stunting. The physiologies of height-stunted children prioritize fat over lean mass deposition, resulting in lower fat-free mass and a tendency toward greater fat-mass accumulation when nutritional resources become available. The overall effect is an increased tendency toward obesity. Height-stunted youth demonstrate greater insulin sensitivity and lower insulin levels, making them prone to developing type 2 diabetes. Stunting arising from prolonged undernutrition also alters thyroid function, lowering the basal metabolic rate in stunted individuals. ${ }^{7}$ No less serious are the reproductive effects of stunting on women: greater risk of stillbirths, preterm birth and neonatal death; complications with labour; and decreased offspring birth weight. ${ }^{8}$ Stunting also has negative consequences for neurologic, psychological and immune system development and function. ${ }^{7}$
Hunger itself has profound consequences for childhood development. Children experiencing hunger have an activated hypothalamic-pituitary-adrenal stress response. This causes increased cortisol secretion which, over the long term, blunts insulin response, inhibits the function of insulin-like growth factor and produces long-term changes in lipid metabolism. ${ }^{7}$ Through this process, the child's physiology is essentially "programmed" by hunger to continue the cycle of worsening effects, with their bodies displaying a rapid tendency for fatmass accumulation when nutritional resources become available. ${ }^{9}$

Studies of children exposed to the 20th-century famines in the Netherlands, Russia and China report greater prevalence of obesity, overweight, diabetes and hypertension; greater incidence of heart attack and stroke; elevated fasting plasma glucose and unfavourable lipid profiles among famine survivors compared with nonstressed controls. ${ }^{7}$ It is clear that sustained exposure to caloric restriction, such as that experienced by children at Canada's residential schools, produces a biological complex of height stunting together with metabolic changes that lead to greater risk of obesity and chronic disease.

The effects of childhood undernutrition are not limited to the life course alone. Infants born to women whose obesity and diabetes arose through childhood undernutrition are more likely to experience interuterine growth failure, both low and high birth weight and growth faltering, and they are more likely to go on to develop insulin resistance and diabetes as children, youth and young adults. ${ }^{7}$ And these effects are not limited to the second generation: studies ${ }^{10}$ showing the developmental consequences of hunger (elevated body mass index and risk of obesity) in the adult grandchildren of the famine survivors.

Hunger has always been central to survivors' accounts of their residential school experiences and we strongly believe that this testimony must be taken more seriously by researchers and medical practitioners. In light of recent evidence showing the connections between childhood hunger and chronic disease risk both in adult- 
hood and in succeeding generations, we can now be fairly certain that the elevated risk of obesity, early-onset insulin resistance and diabetes observed among Indigenous peoples in Canada arises, in part at least, from the prolonged malnutrition experienced by many residential school survivors. ${ }^{7}$ This assessment, moreover, is further reinforced by a recent landmark study showing that Indigenous children were no more nutritionally stressed than other Canadian children at school entry. ${ }^{11}$

The possibility that generations of health practitioners and researchers may have overlooked childhood malnutrition in residential schools as one of the most important factors influencing Indigenous health in Canada should be a call to action. What does it mean when the disproportionate disease burden currently faced by Indigenous communities is, in large part, the product of a residential system that the TRC has found was nothing short of a cultural genocide? ${ }^{6}$ What does it mean when current therapeutic regimes and research programs have mostly ignored the role of Canadian policies like residential schools in producing the current situation? In part, it means that we need to rethink the current behavioural and pharmacologic approaches to the treatment of metabolic and cardiovascular disease in Indigenous communities. In their place, we need more communitydriven, trauma-informed and culturally appropriate interventions that not only respond directly to the TRC's 94 Calls to Action ${ }^{6}$ but also acknowledge the role of residential schools in determining the current health problems faced by residential school survivors and their families. And, most importantly, we need to demand that the next generation of Indigenous children have access to the kinds of plentiful, healthy, seasonal and traditional foods that were denied to their parents and grandparents, as a matter of government policy.

\section{Ian Mosby PhD}

Dalla Lana School of Public Health at the University of Toronto, Toronto, Ont.; Department of Geography, University of Guelph, Guelph, Ont.

\section{Tracey Galloway PhD}

Department of Anthropology, University of Toronto-Mississauga, Toronto, Ont.

\section{References}

1. The survivors speak: a report of the Truth and Reconciliation Commission of Canada. Ottawa: Truth and Reconciliation Commission of Canada; 2015:71-2.
2. Moses R. Mohawk Institute, 1942-47. LAC, RG10, File 1/25-20-1, Vol. 1. 1965.

3. Johnston B. Indian School Days. Toronto: Key Porter; 1988.

4. Miller JR. Shingwauk's vision: a history of native residential schools. Toronto: University of Toronto Press; 1996:290.

5. Mosby I. Administering colonial science: nutrition research and human biomedical experimentation in Aboriginal communities and residential schools, 1942-1952. In: Histoire sociale/Social History, Vol. 46, No. 1. Toronto: University of Toronto Press; 2013:145-72.

6. Honouring the truth, reconciling for the future: summary of the final report of the Truth and Reconciliation Commission of Canada. Ottawa: Truth and Reconciliation Commission of Canada; 2015: 92.

7. Mosby I, Galloway T. "The abiding condition was hunger": Assessing the long-term biological and health effects of malnutrition and hunger in Canada's residential schools. Br J Can Stud. In press; to be published in September 2017, Vol. 30.

8. Institute of Medicine of the National Academies. Dietary reference intakes for energy, carbohydrate, fiber, fat, fatty acids, cholesterol, protein, and amino acids. Washington: National Academies Press; 2005.

9. Martins VJ, Toledo Florêncio TM, Grillo LP, et al. Long-lasting effects of undernutrition. Int J Environ Res Public Health 2011;8:1817-46.

10. Stein AD, Lumey LH. The relationship between maternal and off-spring birth weights after maternal prenatal famine exposure: The Dutch Famine Birth Cohort Study. Hum Biol 2000;72:641-54.

11. Hackett FJ, Abonyi S, Dyck RF. Anthropometric indices of First Nations children and youth on first entry to Manitoba/Saskatchewan residential schools 1919 to 1953. Int J Circumpolar Health 2016; 75:30734.

This article has been peer reviewed. 